NBER WORKING PAPER SERIES

ON THE DESIRABILITY OF FISCAL
CONSTRAINTS IN A MONETARY UNION

V.V. Chari

Patrick J. Kehoe

Working Paper 10232

http://www.nber.org/papers/w10232

\author{
NATIONAL BUREAU OF ECONOMIC RESEARCH \\ 1050 Massachusetts Avenue \\ Cambridge, MA 02138 \\ January 2004
}

The views expressed herein are those of the authors and not necessarily those of the Federal Reserve Bank of Minneapolis or the Federal Reserve System. The views expressed herein are those of the authors and not necessarily those of the National Bureau of Economic Research.

(C)2004 by V.V. Chari and Patrick J. Kehoe. All rights reserved. Short sections of text, not to exceed two paragraphs, may be quoted without explicit permission provided that full credit, including (C notice, is given to the source. 
On the Desirability of Fiscal Constraints in a Monetary Union

V.V. Chari and Patrick J. Kehoe

NBER Working Paper No. 10232

January 2004

JEL No. F3, F4, F41, F42, F33, E5, E58, E63

\begin{abstract}
The desirability of fiscal constraints in monetary unions depends critically on whether the monetary authority can commit to follow its policies. If it can commit, then debt constraints can only impose costs. If it cannot commit, then fiscal policy has a free-rider problem, and debt constraints may be desirable. This type of free-rider problem is new and arises only because of a time inconsistency problem.
\end{abstract}

\author{
V.V. Chari \\ Department of Economics \\ University of Minnesota \\ Minneapolis, MN 55455 \\ and NBER \\ Patrick J. Kehoe \\ Research Department \\ Federal Reserve Bank of Minneapolis \\ 90 Hennepin Avenue \\ Minneapolis, MN 55480-0291 \\ and NBER \\ pkehoe@res.mpls.frb.fed.us
}


In the last decade, the subject of how best to design monetary unions has been attracting more academic interest. A central issue in designing such unions is whether constraints should be imposed on the fiscal policies of the member states. Here we address this question using standard economic models with benevolent policymakers. Our answer is that the desirability of fiscal constraints depends critically on whether the union's monetary authority can commit to its future policies. If this authority can commit, then fiscal constraints on member states will not increase welfare, but if it cannot commit, then such constraints will increase welfare.

The driving force behind our results is that a time inconsistency problem in monetary policy leads to a free-rider problem in fiscal policy. The time inconsistency problem arises because the monetary authority has an incentive to inflate away nominal debt. Without commitment to future policy, a benevolent monetary authority's optimal policy is to set high inflation rates when the inherited debt levels of the member states are high and low inflation rates when they're low. The cost of inflation is borne by the residents of all the member states. When a fiscal authority in a member state is deciding how much debt to issue, it recognizes that as it increases its own debt, the monetary authority will increase the inflation rate. The fiscal authority takes account of the costs of the induced inflation on its own residents, but ignores the costs this induced inflation imposes on other member states. This free-rider problem leads to inefficient outcomes, each fiscal authority will issue too much debt, and the inflation rate will be too high. Imposing constraints on the amount of debt that each fiscal authority is allowed to issue can thus make all the member states better off.

If some way can be found to solve the monetary union's time inconsistency problem, then the free-rider problem disappears, and imposing fiscal constraints will typically reduce welfare. In our simple model, the only way to solve the time inconsistency problem is to assume that the monetary authority can commit. In richer models, even without commitment, reputational benefits can solve the time inconsistency problem, eliminate the free-rider problem, and make debt constraints unnecessary and possibly harmful.

The idea that groups of various forms, such as members of a monetary union, may have a variety of free-rider problems in either static models or models with commitment is not new. What we find here, though, is new: we identify a new type of free-rider problem, one which arises only because there is a time inconsistency problem. We show that this free-rider 
problem can be solved by the appropriate choice of fiscal constraints on debt. Moreover, the type of problem we identify is clearly relevant for policy. The logic of how these constraints prevent the problem seems to capture well the arguments made for fiscal constraints by the framers of the agreements which established the European Monetary Union (EMU).

We illustrate our results in the simplest possible framework, a reduced-form twoperiod benchmark model. In the first period of this model, fiscal authorities of states in a monetary union issue nominal debt to risk-neutral lenders who live outside the union; in the second period, the union's monetary authority decides the common inflation rate. We assume that second-period output is a decreasing function of the inflation rate, so that the monetary authority balances the benefits of devaluing nominal debt against the costs of reducing output. The larger the debt the monetary authority inherits, the higher it wants to set the inflation rate and, without some mechanism to prevent that, the higher it sets the inflation rate. Thus, without monetary policy commitment, when one of the fiscal authorities issues more debt, the others are made worse off. This free-rider problem implies that the level of debt in a noncooperative equilibrium is different from that in a cooperative equilibrium. If the monetary authority instead commits to its policies, then the union has no free-rider problem.

In the Appendix, we show that the results from our benchmark model do not depend on government default to lenders who live outside the monetary union. We describe a slightly modified model in which governments borrow from their own consumers, and we show that in it results similar to the benchmark's hold. In this modified model, the monetary authority trades off reduced output from higher inflation against the need for each fiscal authority to raise revenue through distorting taxes. Notice that in both models, the monetary authority trades off the costs of higher inflation against its benefits. In our benchmark model, the benefit of inflation is defaulting on foreign debt. In the modified model, it is reducing the need to levy distorting taxes.

Our theory provides a new lens through which to analyze existing monetary unions. The most high-profile union lately, of course, is the EMU, and the most controversial aspect of that union is the fiscal policy constraints embedded in the agreements which set it up, the Maastricht Treaty and the Stability and Growth Pact. 
Our theory provides a rationale for those fiscal policy constraints. One reading of the EMU agreements is that, notwithstanding the solemnly expressed intent to make price stability the monetary authority's primary goal, in practice, monetary policy is set sequentially by majority rule. In such a situation, the time inconsistency problem in monetary policy is potentially severe, and as our analysis shows, debt constraints are desirable. Our analysis is consistent with the view that the EMU framers thought that committing to monetary policy would be extremely difficult and therefore wisely made debt constraints an integral part of the agreements.

An alternative reading of these agreements, of course, is that the primacy of the goal of price stability and the independence of the monetary authority effectively ensure commitment to future monetary policy and thereby solve the time inconsistency problem. If one accepts this reading, then as our analysis with commitment indicates, debt constraints are unnecessary and possibly harmful. (For a forceful argument that debt constraints are harmful, see Buiter et al.'s 1993 work.)

Our theory also provides a new lens through which to analyze monetary policy in countries in which individual state governments have considerable freedom in setting their fiscal policies. Our theory suggests that in such monetary unions, unresolved time inconsistency problems in monetary policy lead to high inflation and profligate fiscal policy.

Argentina is a good example of such a country. It apparently has a serious time inconsistency problem with its monetary policy and, regardless of its good intentions, is unable to set effective constraints on its provincial governments. These provincial governments routinely run budget deficits that end up being financed by the central bank (Nicolini et al. (2002)). Expectations of bailouts have increased the provinces' incentives to behave in a financially profligate manner. Indeed, one rationale for Argentina's 1991 convertibility law, which linked the peso to the dollar, is the hope of restraining that sort of behavior. Jones et al. (2000) find some evidence that fiscal deficits among these Argentine governments fell after the imposition of convertibility, though the recent collapse of the currency board suggests that the time inconsistency problems in monetary policy were not solved by the legal changes. (For related discussions of Argentina, see the work of Cooper and Kempf (2001a and b) and Tommasi et al. (2001).) 
The United States is another example of a country which can be viewed as a monetary union. It, however, appears to have solved the time inconsistency problem in monetary policy, so that there is no free-rider problem among the states.

Beyond these examples, of course, are many others. Von Hagen and Eichengreen (1996) have assembled data on fiscal policy restrictions in 49 countries, each of which can be viewed as a collection of subcentral governments, constituting a monetary union. Von Hagen and Eichengreen find that 37 of these countries impose restrictions on the fiscal policies of their subcentral governments. This finding suggests that, in practice, policymakers are concerned with what we study here: the desirability of constraining the fiscal behavior of members of a monetary union.

Our research here is related to a literature on fiscal policy in monetary unions, including the work of Sibert (1992), Beetsma and Uhlig (1999), Dixit and Lambertini (2001), Uhlig (2002), Ching and Devereux (2003), and Cooper and Kempf (forthcoming). The studies of Uhlig and Cooper-Kempf are the most closely related to our work here. Uhlig develops a reduced-form model in which fiscal policy has a free-rider problem. In his model, that problem ends up reducing welfare, but not raising the inflation rate. Cooper and Kempf focus mostly on the gains to a monetary union with commitment by the monetary authority and show that without commitment, the monetary union itself may be undesirable.

An extensive literature has discussed the gains from international cooperation in setting fiscal policy. This literature shows that cooperation is desirable if a country's fiscal policy affects world prices and real interest rates. (For details on this result, see the work of Chari and Kehoe (1990) and Canzoneri and Diba (1991).) The kind of desirable cooperation that this literature points to applies to the relationship between, for example, Germany and Canada as well as to that between Germany and Italy; it is not especially related to countries being in a monetary union. Because the issues raised in this literature are well understood, we abstract from them here. We do so by considering models in which the fiscal policies of the cooperating countries taken as a group do not affect world prices and real interest rates. In such models, there can be no gains to cooperation of this sort. 


\section{The Basic Economy}

Consider a two-period model with a monetary union consisting of $I$ identical countries, each of which is small in the world economy. In period 0, the countries start with an identical price level $p_{0}$, which is given. Each country issues nominal debt in period 0 to lenders who live outside the monetary union. There are a large number of such lenders, each of whom is risk neutral and has a discount factor $\beta$. In period 1 , the monetary authority sets the monetary policy for the union. We model monetary policy by simply letting the monetary authority directly choose the price level in period $1, p_{1}$. In all countries, in period 0 , output is a constant given by $\omega$, while in period 1 , output $y(\pi)$ is a decreasing and concave function of the common inflation rate from period 0 to period 1 , denoted by $\pi=p_{1} / p_{0}$.

The budget constraints of the government in country $i$ are

$$
\begin{aligned}
& p_{0} c_{i 0}=\omega+b_{i} \\
& p_{1} c_{i 1}=p_{1} y(\pi)-x_{i}
\end{aligned}
$$

where $c_{i 0}$ and $c_{i 1}$ denote consumption of the residents of country $i$ in the two periods, $b_{i}$ is nominal debt sold to foreign lenders by country $i$, and $x_{i}$ is the nominal repayment associated with country $i$ 's debt. Let $\left(b_{i}, x_{i}\right)$ denote the debt contract of country $i$. Clearly, the gross nominal interest rate on debt implicit in this contract is $R_{i}=x_{i} / b_{i}$. In equilibrium, the nominal interest rate is the same across countries.

The model starts with $p_{0}$ given, so for convenience, we set $p_{0}=1$. We can then write $(2)$ as $c_{i 1}=y(\pi)-x_{i} / \pi$. The government in country $i$ maximizes the welfare of its representative consumer, given by

$$
U\left(c_{i 0}\right)+\beta U\left(c_{i 1}\right) .
$$

We will assume that $\omega$ (output in period 0) is sufficiently smaller than $y(1$ ), so that the governments have an incentive to borrow. The monetary authority's objective function is an equally weighted average of the objective functions of the governments in the union. The profit of a lender who agrees to accept a debt contract $\left(b_{i}, x_{i}\right)$ is given by $-b_{i}+\beta x_{i} / \pi$. Let $\bar{b}=\left(b_{1}, \ldots, b_{I}\right)$ and $\bar{x}=\left(x_{1}, \ldots, x_{I}\right)$ summarize the debt contracts. 


\section{Equilibrium Without Commitment}

We model lack of commitment in monetary policy by having the monetary authority choose the inflation rate after the governments and the lenders have chosen their debt contracts. Of course, when choosing a debt contract, each government recognizes that its choice will affect inflation by influencing monetary policy. Specifically, the model's timing is that governments choose their debt contracts simultaneously at the start of period 0 . Then the lenders decide whether to accept the contracts. Finally, in period 1, the monetary authority chooses the common inflation rate $\pi$ as a function of the repayments $\bar{x}$ in the contracts.

We consider two regimes: a noncooperative regime, in which the governments simultaneously choose their debt contracts to maximize their own objective functions, and a cooperative regime, in which the governments choose the debt contracts to maximize the equally weighted average of their objective functions.

In both regimes, we solve the model by starting at the end. Consider first the monetary authority and the lenders. Their problems are the same in both regimes. Taking the repayments $\bar{x}$ in the debt contracts as given, the monetary authority chooses $\pi$ to solve

$$
\max _{\pi} \frac{1}{I} \sum_{i=1}^{I} U\left(y(\pi)-x_{i} / \pi\right) .
$$

Let $\pi(\bar{x})$ denote the resulting monetary policy rule. Consider next the lenders. Profit maximization implies that the lenders will accept any contract that yields nonnegative profits. Thus, any debt contract must satisfy this:

$$
-b_{i}+\beta x_{i} / \pi(\bar{x}) \geq 0 .
$$

In the noncooperative regime, the government of country $i$, taking the debt contracts of other governments $\left(\bar{b}_{-i}, \bar{x}_{-i}\right)$ as given, chooses a debt constraint to solve

$$
\max _{b_{i}, R_{i}} U\left(\omega+b_{i}\right)+\beta U\left(y(\pi(\bar{x}))-x_{i} / \pi(\bar{x})\right)
$$

subject to the constraint (5) that lenders accept the contract. A noncooperative equilibrium $(N)$ is a monetary policy rule $\pi(\bar{x})$ that solves $(4)$ and debt contracts $\left(\bar{b}_{N}, \bar{x}_{N}\right)$ that solve (6). In the cooperative regime, the debt contracts $(\bar{b}, \bar{x})$ are instead chosen to solve

$$
\max _{\bar{b}, \bar{R}} \frac{1}{I} \sum_{i=1}^{I}\left[U\left(\omega+b_{i}\right)+\beta U\left(y(\pi(\bar{x}))-x_{i} / \pi(\bar{x})\right)\right]
$$


subject to (5). A cooperative equilibrium $(C)$ is a monetary policy rule $\pi(\bar{x})$ that solves $(4)$ and debt contracts $\left(\bar{b}_{C}, \bar{x}_{C}\right)$ that solve $(7)$.

Notice that the monetary policy rule is identical in the two equilibria. The equilibrium inflation rates and interest rates differ because the noncooperative and cooperative debt and repayment levels differ.

We restrict consideration to symmetric equilibria in which the debt contracts are the same in all the countries. We then have

Proposition 1. Welfare measured by (3) in the symmetric cooperative equilibrium is greater than welfare in any noncooperative equilibrium.

Proof. The noncooperative equilibrium allocations are feasible choices for the governments in the cooperative regime. Thus, if the cooperative equilibrium allocations differ from those in the noncooperative equilibrium, then welfare in the cooperative equilibrium is greater than welfare in the noncooperative equilibrium.

We show that the allocations in the two equilibria differ by showing that the firstorder conditions evaluated at the equilibrium allocations must differ. In both equilibria, the first-order condition for the monetary authority is given by

$$
\sum_{i=1}^{I} U^{\prime}\left(c_{i 1}\right)\left(y_{\pi}+x_{i} / \pi^{2}\right)=0
$$

In a symmetric equilibrium, the monetary authority's first-order condition reduces to $y_{\pi}+$ $x / \pi^{2}=0$. Notice that in both equilibria, utility maximization implies that (5) holds with equality. Thus, in both, we can substitute for $b_{i}$ using (5) with equality and then maximize only with respect to $x_{i}$.

The first-order condition for government $i$ in a symmetric noncooperative equilibrium is given by

$$
\left[U^{\prime}\left(c_{0}\right)-U^{\prime}\left(c_{1}\right)\right]+\frac{x}{\pi} U^{\prime}\left(c_{0}\right) \frac{\partial \pi}{\partial x_{i}}=0
$$

The analogous first-order condition in a symmetric cooperative equilibrium is that

$$
\left[U^{\prime}\left(c_{0}\right)-U^{\prime}\left(c_{1}\right)\right]+\frac{x}{\pi} U^{\prime}\left(c_{0}\right) \frac{\partial \pi}{\partial x_{i}}=(I-1) \frac{x}{\pi} U^{\prime}\left(c_{0}\right) \frac{\partial \pi}{\partial x_{i}} .
$$


To show that (9) and (10) differ, we need only show that $\partial \pi / \partial x_{i}$ is nonzero. To do so, we differentiate the monetary authority's first-order condition with respect to $x_{i}$ to obtain this:

$$
\frac{\partial \pi}{\partial x_{i}}=\left(\frac{1}{I}\right) \frac{U^{\prime \prime}\left(c_{1}\right) / \pi-U^{\prime}\left(c_{1}\right) / \pi^{2}}{U^{\prime}\left(c_{1}\right)\left(y_{\pi \pi}-2 x / \pi^{3}\right)}
$$

which is clearly positive since $y$ is concave. Q.E.D.

We now show that if we add fiscal constraints in the noncooperative regime, we can im-

plement the cooperative allocation. These constraints take the form of limits on the amount of debt a government can issue. Assuming that the first-order conditions for the noncooperative equilibrium are sufficient for optimality, we have the following proposition:

Proposition 2. If each country $i=1, \ldots, I$ in the noncooperative regime faces the constraint $b_{i} \leq b_{C}$, then the cooperative allocations are also a noncooperative equilibrium.

Proof. In the noncooperative regime, the increment to welfare of a small increase in $x_{i}$ is given by the left side of (9). Consider evaluating this increment at the cooperative allocations. From (10) and the result that $\partial \pi / \partial x_{i}$ is positive, we have that the left side of (9) is positive. Thus, at the cooperative allocations, a noncooperative government has an incentive to increase $x_{i}$ and also $b_{i}$, since $b_{i}=\beta x_{i} / \pi$. Q.E.D.

When the number of countries $I$ in the monetary union is large, the first-order conditions in the noncooperative equilibrium are sufficient for optimality because $\partial \pi / \partial x_{i}$ goes to zero as $I$ goes to infinity, and the resulting problem is necessarily concave.

Thus, we have shown here that without monetary policy commitment in a monetary union, fiscal constraints are desirable.

\section{Equilibrium With Commitment}

So far, we have assumed that the monetary authority cannot commit to its policy. This lack of commitment turns out to be crucial for our result that debt constraints improve welfare. We show now that when the monetary authority can commit, the noncooperative and cooperative equilibria coincide, so that debt constraints can, at best, leave welfare unaffected.

We change the timing of our model to allow for commitment by the monetary authority. Specifically, now the monetary authority chooses the inflation rate first, and the governments 
then choose debt contracts. Clearly, in this scenario, the inflation rate cannot depend on the debt contracts. Profit maximization implies that lenders will accept any contract that yields nonnegative profits, so that any debt contract with country $i$ must satisfy this:

$-b_{i}+\beta x_{i} / \pi \geq 0$

In the noncooperative regime, then, the government of country $i$ solves

$$
\max _{b_{i}, x_{i}} U\left(\omega+b_{i}\right)+\beta U\left(y(\pi)-x_{i} / \pi\right)
$$

subject to $(11)$. Let $\left(b_{i}(\pi), x_{i}(\pi)\right)$ denote the debt-contracting rule in the noncooperative regime for $i=1, \ldots, I$. The monetary authority takes as given the debt-contracting rules for each government and solves

$$
\max _{\pi} \frac{1}{I} \sum_{i=1}^{I}\left[U\left(\omega+b_{i}(\pi)\right)+\beta U\left(y(\pi)-x_{i}(\pi) / \pi\right)\right] .
$$

Here a noncooperative equilibrium is a monetary policy $\pi$ that solves (13) and debt contracts $\left(\bar{b}_{N}(\pi), \bar{x}_{N}(\pi)\right)$ that solve $(12)$.

In the cooperative regime, the debt contracts $(\bar{b}, \bar{x})$ are chosen to solve

$$
\max _{\bar{b}, \bar{R}} \frac{1}{I} \sum_{i=1}^{I}\left[U\left(\omega+b_{i}\right)+\beta U\left(y(\pi)-x_{i} / \pi\right)\right]
$$

subject to (11). Inspection of (12) and (14) makes clear that the debt-contracting rules are the same in the two regimes. And the problem of the monetary authority in the cooperative regime is again given by (13). A cooperative equilibrium is a monetary policy rule $\pi(\bar{x})$ that solves (4) and debt contracts $\left(\bar{b}_{C}(\pi), \bar{x}_{C}(\pi)\right)$ that solve $(14)$.

Since the debt-contracting rules are the same in the two regimes, this follows:

Proposition 3. With commitment by the monetary authority, the noncooperative and cooperative equilibria coincide.

Propositions 2 and 3 taken together imply that the question of whether debt constraints are desirable is intimately connected to whether the monetary authority can commit to future monetary policy. Proposition 3 says that, with commitment, binding constraints on issuing debt reduce welfare unless they are chosen to be exactly equal to the debt levels in the cooperative equilibrium. Proposition 2 implies that as long as such commitment is not possible, appropriately chosen debt constraints strictly improve welfare. 


\section{Conclusion}

Here we have shown that the desirability of debt constraints in a monetary union depends critically on whether the monetary authority can commit to its policies. If it can commit, then debt constraints are not desirable; they can only impose costs. But if the monetary authority cannot commit, then the time inconsistency problem in monetary policy produces a free-rider problem in fiscal policy, and debt constraints are desirable. 


\section{Appendix: An Economy With Domestic Lenders}

For simplicity, we have assumed above that all debt of the monetary union is held by foreigners. Here we sketch the analysis in a related model in which all debt is instead held by residents of the monetary union. To establish that our results do not depend on foreigners holding the union's debt, we assume throughout that all the government debt of a country in the union is held by consumers in that country.

Consider first the preferences of country $i$ :

$$
U\left(c_{i 0}\right)+V\left(g_{i}\right)+\beta U\left(c_{i 1}\right)
$$

where $c_{i 0}$ and $c_{i 1}$ denote private consumption in the two periods, $g_{i}$ is government consumption in period $0 ; U(\cdot)$, the utility from private consumption; and $V\left(g_{i}\right)$, the utility from government consumption. In each country $i$, output in period 0 is a constant given by $\omega$, while output in period 1 is given by $y\left(\pi, T_{i}\right)$, where $\pi$ denotes the common inflation rate and $T_{i}$ denotes tax revenues in period 1 . To ensure that real interest rates are unaffected by policy, we assume that consumers have access to a linear saving technology with exogenous gross return $1+r$.

Consider next the budget constraints of the government and the consumers. For simplicity, assume that government consumption is financed entirely by debt issue. The debt contract of government $i$ is denoted by $\left(b_{i}, x_{i}\right)$, where $b_{i}$ is the amount of nominal debt and $x_{i}$ is the nominal repayment on the debt. The budget constraints of the government in country $i$ are $b_{i}=g_{i}$ and $T_{i}=x_{i} / \pi$. The budget constraints of the consumer in country $i$ are $c_{i 0}=\omega-k_{i}-b_{i}$ and $c_{i 1}=y\left(\pi, T_{i}\right)+(1+r) k_{i}+x_{i} / \pi-T_{i}$, where $k_{i}$ denotes savings in the storage technology. Notice that we have assumed that all the debt of the government of country $i$ is held by the consumers of that country. We assume throughout that $\omega$ is sufficiently small so that the equilibrium is interior, in the sense that both $k_{i}$ and $b_{i}$ are positive. Let $\bar{b}=\left(b_{1}, \ldots, b_{I}\right)$ and $\bar{x}=\left(x_{1}, \ldots, x_{I}\right)$ summarize the debt contracts.

The timing of this model without commitment is as follows. In period 0 , the governments choose their debt contracts $\left(b_{i}, x_{i}\right)$ and government consumption levels $g_{i}\left(=b_{i}\right)$ simultaneously. Then consumers make saving decisions $s_{i}$ which, given $b_{i}$, determine the amount stored $k_{i}$. In period 1 , the monetary authority chooses the common inflation rate $\pi$ as a 
function of the repayments $\bar{x}$ in the debt contracts and the stored amounts $\bar{k}=\left(k_{1}, \ldots, k_{I}\right)$. Finally, the governments choose tax revenues $T_{i}$ to satisfy their budget constraints.

To set up the equilibrium, we work back from the end of period 1 . Given $\pi$ and $x_{i}$, the government decision in period 1 is determined by $T_{i}=x_{i} / \pi$. The monetary authority chooses $\pi$ to solve

$$
\max _{\pi} \frac{1}{I} \sum_{i=1}^{I} U\left(y\left(\pi, \frac{x_{i}}{\pi}\right)+(1+r) k_{i}\right) .
$$

In (15) we have used the budget constraint of the government in period 1 . Let $\pi(\bar{x}, \bar{k})$ denote the resulting monetary policy rule.

Now consider the saving decisions of the consumers. Clearly, in any interior equilibrium, the real rates of return on storage and government debt must be equal, and the first-order condition for savings is given by $U^{\prime}\left(c_{i 0}\right)=\beta(1+r) U^{\prime}\left(c_{i 1}\right)$.

In the noncooperative regime, the government of country $i$, taking other countries' debt contracts and the saving decisions as given, solves

$$
\max _{g_{i}, b_{i}, x_{i}, k_{i}} U\left(\omega-b_{i}-k_{i}\right)+V\left(g_{i}\right)+\beta U\left(y\left(\pi(\bar{x}, \bar{k}), \frac{x_{i}}{\pi(\bar{x}, \bar{k})}\right)+(1+r) k_{i}\right)
$$

subject to the period 0 budget constraint of the government and the first-order condition for consumer savings.

In the cooperative regime, $(\bar{g}, \bar{b}, \bar{x}, \bar{k})$ solve

$$
\max _{\bar{g}, \bar{b}, \bar{x}, \bar{k}} \frac{1}{I} \sum_{i=1}^{I}\left[U\left(\omega-b_{i}-k_{i}\right)+V\left(g_{i}\right)+\beta U\left(y\left(\pi(\bar{x}, \bar{k}), \frac{x_{i}}{\pi(\bar{x}, \bar{k})}\right)+(1+r) k_{i}\right)\right]
$$

subject to the period 0 of government budget constraint and the first-order condition for consumer savings in each country.

A noncooperative equilibrium is a monetary policy rule $\pi(\bar{x}, \bar{k})$ that solves $(15)$ and allocations $\left(\bar{g}_{N}, \bar{b}_{N}, \bar{x}_{N}, \bar{k}_{N}\right)$ that solve (16). A cooperative equilibrium is a monetary policy rule $\pi(\bar{x}, \bar{k})$ that solves $(15)$ and allocations $\left(\bar{g}_{C}, \bar{b}_{C}, \bar{x}_{C}, \bar{k}_{C}\right)$ that solve (17).

The analogs of Propositions 1, 2, and 3 can easily be shown to hold for this model. 


\section{References}

Beetsma, Roel and Harald Uhlig. 1999. An Analysis of the Stability and Growth Pact. Economic Journal 109 (458, October), 546-71.

Buiter, Willem, Giancarlo Corsetti, and Nouriel Roubini. 1993. Excessive Deficits: Sense and Nonsense in the Treaty of Maastricht. Economic Policy: A European Forum 8 (16, April), 57-100.

Canzoneri, Matthew B. and Behzad T. Diba. 1991. Fiscal Deficits, Financial Integration, and a Central Bank for Europe. Journal of the Japanese and International Economy 5 (4, December), 381-403.

Chari, V. V. and Patrick J. Kehoe. 1990. International Coordination of Fiscal Policy in Limiting Economies. Journal of Political Economy 98 (3, June), 617-36.

Ching, Stephen and Michael B. Devereux. 2003. Mundell Revisited: A Simple Approach to the Costs and Benefits of a Single Currency Area. Review of International Economics 11 (4, September), 674-91.

Cooper, Russell W. and Hubert Kempf. 2001a. Dollarization and the Conquest of Hyperinflation in Divided Societies. Federal Reserve Bank of Minneapolis Quarterly Review 25 (3, Summer), 3-12.

. 2001b. On Dollarization. Manuscript. Boston University.

. Forthcoming. Overturning Mundell: Fiscal Policy in a Monetary Union. Review of Economic Studies.

Dixit, Avinash and Luisa Lambertini. 2001. Monetary-Fiscal Policy Interactions and Commitment versus Discretion in a Monetary Union. European Economic Review 45 (4-6, May), 977-87.

Jones, Mark P., Pablo Sanguinetti, and Mariano Tommasi. 2000. Politics, Institutions, and Fiscal Performance in a Federal System: An Analysis of the Argentine Provinces. Journal of Development Economics 61 (2, April), 305-33.

Nicolini, Juan Pablo, Josefina Posadas, Juan Sanguinetti, Pablo Sanguinetti, and Mariano Tommasi. 2002. Decentralization, Fiscal Discipline in Sub-National Governments, and the Bailout Problem: The Case of Argentina. Research Department Working Paper R-467. Inter-American Development Bank. 
Sibert, Anne. 1992. Government Finance in a Common Currency Area. Journal of International Money and Finance 11 (6, December), 567-78.

Tommasi, Mariano, Sebastian Saiegh, and Pablo Sanguinetti. 2001. Fiscal Federalism in Argentina: Policies, Politics, and Institutional Reform. Economia: Journal of the Latin American and Caribbean Economic Association 1 (2, Spring), 157-200.

Uhlig, Harald. 2002. One Money, But Many Fiscal Policies in Europe: What are the Consequences? Discussion Paper 3296. Centre for Economic Policy Research.

Von Hagen, Jurgen and Barry Eichengreen. 1996. Federalism, Fiscal Restraints, and European Monetary Union. American Economic Review 86 (2, May), 134-38. 